\title{
Relevance of Discretionary Accruals Information (DAl) in Ohlson model: the case of Mexico
}

\section{Rocío Durán-Vázquez , Arturo Lorenzo-Valdés**, Juan Manuel San Martín-Reyna ${ }^{* * *}$}

\begin{abstract}
This study applied the modified Jones' model (1991) for selected companies of Mexico. This model aims to assess the impact of Discretionary Accrual Information (DAl) on financial reporting statements, in order to identify the value relevance of "earnings quality". We applied methodological criteria of Chung et al (2005) and Mukit \& Iskandar (2009). We analyzed financial information of the 35 stock included in the Index of Prices and Quotations (IPC) of the Mexican Stock Exchange (BMV) for the period 2000 to 2011. 19 companies met the specifications of the model, for 48 quarters of information. The analysis was done in three parts: first, an analysis of the modified Jones' model under panel data considerations by using fixed effects and adjustments of performing autocorrelation of order 1; second, a correlation analysis between the residuals of the modified Jones' model and the return of stock price in 3 annual closings years of study: 2007, 2008 and 2009; and third, we incorporated this variable (DAI) in the Ohlson model (of the financial and corporate accounting literature) and we tested it with panel data analysis, under fixed effects, throughout the study period.

Keywords: financial markets, Jones and Ohlson Models, econometric estimation.
\end{abstract}

\section{Introduction}

What do we mean by "earnings quality"? We identify a "high quality earnings" when they faithfully represent the characteristics of the fundamental processes of the company, and they are relevant for decision making (under managerial point of view).

* Dra. Rocío Durán-Vázquez, Department of Finance and Accouting, Universidad de las Américas Puebla, Ex-hacienda Santa Catarina Martir S/N, Cholula, Puebla, México, rocio.duran@udlap.mx.

** Dr. Arturo Lorenzo-Valdés, Department of Finance and Accouting, Universidad de las Américas Puebla, Ex-hacienda Santa Catarina Martir S/N, Cholula, Puebla, México, arturo.lorenzo@udlap.mx.

*** Dr. Juan Manuel SanMartin-Reyna, Department of Business Management, Universidad de las Américas Puebla, Ex-hacienda Santa Catarina Martir S/N, Cholula, Puebla, México, juanm.sanmartin@udlap.mx. 
Of course, the term "earnings quality" is meaningless without specifying the context of decision making.

This concept was popularized by Lev (1989) when he incorporated the term "quality" as a descriptive characteristic of the profits (profit or loss of business, involving both gains and losses). And as it is linked to the utility (relevance) in decisionmaking, it has taken different paths of research, as highlighted Schelling (1978). In this paper we identify the "quality of earnings" as the ones with less "discretionary accrual information". Specifically, we define Discretionary Accrued Information (DAI) as the difference between the Total Accrued Information (TAI) of the companies, minus No Discretionary Accrued (NDA) portion.

And what does "Total Accrued Information" (TAI) consider? TAl is the difference between operating income (profit or loss, under accrual basis of accounting) minus the flow generated from operations. And the "No Discretionary Accrued" portion is the corresponding adjustments and estimates of the financial information that are clarified in the accounting policies of the items of working capital, financing and investment. This definition is consistent with the literature, starting from DeAngelo (1986), Healy (1985) and McNichols and Wilson (1988). The main interest of this is because the "Discretionary Accrual Information" (DAI) represents opportunistic practice that can be carried out for more management gains direct benefit from them, including impairment of the company. As highlighted Castrillo and San Martin (2008), this behavior implies downside to shareholders and can be identified as a "technique for handling finances."

Jones (1991) proposed to calculate this "variable" and measured with a statistical or non-existent behavior, using the residuals of the model that bears her name. It allows the calculation of discretionary accrual information as a measure to identify the existence of accounting manipulation in terms of the detriment of the quality of earnings presented in financial reports.

That is why the focus of the study is to identify the "discretionary portion" for evidence of the existence of information manipulation for decision making at the management level of enterprises. And the purpose besides it is to test the value relevance of the "discretionary portion" on the stock market, when it is evaluated as an additional variable to the model of Ohlson (which brings value relevance of financial information in the price).

The approach of the analysis began with the measure of this issue of discretionary accrual information, using the modified Jones' model (1991), then we tested its relevance by adding this variable in a model of corporate finance literature: the Ohlson model (1994), which has been applied to the Mexican data, as presented in Duran, Lorenzo and Valencia (2007) using panel data analysis with fixed effects finding the relevance of the model with Mexican data; and in Lorenzo and Duran (2010) using cointegration test finding balance in the long term of the Mexican variables (meaning that the Ohlson model has value relevance in Mexican' companies, as in development countries). 


\section{Literature review}

\section{Accrual Financial Information}

There are several studies that identify approaches and impact on the calculation of the "discretionary accrual information", especially given the responsibility and decision of the board in this regard.

The administration tends to have a "margin" of action in choosing alternative financial information, which is a veil of opportunistically "possible" manipulation on the income statement (generating a different profit or loss according with some managerial objective). That is why the popular perception has it that cash flows should provide more significance of a company's performance, however empirical studies initiated by Dechow (1994) find evidence that the significance of the performance of the company is in information accrual, instead of cash flows (widely accepted by finance literature). We emphasize this point because financial analysts typically have considered aspects estimates accrued income statement as weaken-altering information offered by utilities, which has led to the idea that cash flows could provide more information. Dechow, (1994) referring to the press articles, as published in Chemical Week (May 8, 1991, p. 28), says: "Many financial analysts consider operating cash flow as a better indicator of financial performance of companies net profits as it is less subject to distortion of different accounting practices. " However, profits have econometrically showed greater significance.

Accrual adjustments are made to represent the situation with greater significance and financial performance of companies, fulfilling the criteria of the framework of financial reporting regulations, both nationally and internationally. These accruals are used by seeking to improve the quality of financial reporting accounting, as highlighted Hansen and Noe (1998) and Barth, Cram and Nelson (2001).

Research in this area is complicated because the managers are those with the informational advantage on the use accruals, and analysts have only as the amounts reflected in the annual reports. That is why the study becomes relevant. Jones (1991) began by identifying the formation of total information accrual underlying the financial statements of companies, the breakdown of the items forming "obvious" accruals, performing adjustments to their model, as the approach of Xie, and DaDalt Davison (2003) to target the adjusted working capital as was also identified in Dechow (1994). Since the total information accrual includes discretionary and non-discretionary portions, it is necessary to specify each one, such as highlights Poveda (2001).

For the empirical analysis of this issue, there are approaches in cross-sectional and in time series analysis. The one that is the most used is the cross sectional analysis with the most frequent data under quarterly basis. There is mainly evidence of regressions (cross-sectional analysis) in the majority of studies, precisely because for a time-series analysis it will require numerous observations and it is complicated to conduct it, as well as being the information it is susceptible to structural changes over time. A sample of the comparison between the results of time series and cross sections are the studies 
by Shvakumar (1996), Subramanyam (1996) and DeFond and Subramanyam (1998), where they found the strength and statistical significance in the regressions, following the this path in mainly literature' references.

Before the modified model of Jones (1991), Healy (1985) and DeAngelo (1986) were consistent to identify the portion of discretionary accrual information (under the usual accounting considerations).

Since in the literature we find mainly uses cross-sectional, this study explores the significance of the modified model of Jones (1991), under the panel data analysis, assessing the existence of fixed effects, since it has no evidence for Mexican companies.

The importance of accounting accrual accounts is that the information on Balance Sheet shows combination between past and present results of the company (because there are items that are aggregated over time and other are only for the period). And if it highlighted the discretionary part, the next step is to see if it has an impact on market behavior. It is here the importance of this study, because we are joining two main issues of study: one about the "earnings quality" (considering the discretion of managers in financial reporting) and the other, that is concerned with how this information may or may not be directly relevant to explain the stock price of the companies that are listed on the Mexican Stock Exchange. In both parts we are following one of the main objectives of financial reporting empirical research: to find evidence that accounting is relevant for decisions of investors' valuation.

In the work of Garcia and Gill (2005) we found evidence of 155 Spanish companies which additionally applied a questionnaire to identify the mechanisms that may contribute to good corporate governance practice and applied the Jones' model to determine the handling of results. It was consistent with the results of Azofra, Castrillo and Del Mar (2006), about the ability of the model to detect manipulation that Jones obtained from Spanish companies. And Aminul, Ali and Ahmad (2011) analyzes the modified Jones model in detecting earnings manipulation between IPOs listed from 1985 to 2005 in the Dhaka Stock Exchange, reaching the conclusion that there was no sufficient data in Bangladesh.

\section{Relevance of financial information in the stock market}

There are several studies in this area, since Ball and Brown (1968) we find evidence of the association between the price of shares in the stock market and accounting profits of companies. Within accounting models that evaluate financial and accounting information highlights, the "EBOF reference model", named after the initials of the researchers Edwards, Bell, Ohlson and Feltham, is presented in Ohlson (1994). This model has been used in several magazine articles to evaluate Accountants American companies traded. The variables used in the model to explain the price market value of the company are: the Book Value (Shareholders' equity in book value) and Earnings (profits or losses for the year).

The Ohlson model is the one with the largest number of research papers in the international accounting literature, with different interpretations emphasizing its 
utility or reflecting about their structural and methodological constraints. And it means a crucial reference for the market analysis based on financial accounting research, because the financial information was considered and identified as a component of value. And it allows the link of relevance of accrual financial information with the response of the stock market.

In essence this model reflects the value of the company into two main parts: the value of the net investment in it (book value) and the present value of the benefits period (income) that brings together the "net assets" Shareholders' Equity value concept.

Particularly, Ohlson (1995) motivates the adoption of pricing model in studies of value relevance, expressing its value in terms of earnings and book values. The current use of historical data base of stocks, began with Collins-Maydew-Weiss (1997), as highlighted the relevance of their use, reporting its significance within the U.S. market, particularly highlighting three results: First, counter adverse opinions of the professional literature, the combined value-relevance of earnings and shareholders' equity has declined over the past 40 years, in fact it seems to have increased a bit. Second, while the incremental value-relevance of earnings has a declining line, it has been replaced by the increase in the value-relevance of stockholders. Third, much of the change in the value-relevance of earnings to stockholders can be explained by: the increase in the frequency and magnitude of ordinary results in profits, an increase in the frequency of negative earnings, and change in average firm size and intensity of intangibles in companies over time.

Since 1995, the Ohlson model has been extensively tested with data from the United States and various developed countries and a few developing ones. Within the accounting literature, there are few applications that use data from Latin America and even less information using the Mexican stock market. Duran, Lorenzo and Valencia (2007) found relevant value in Ohlson model by panel data analysis for the entire market of Mexico from 1991 to 2003 and Lorenzo and Duran (2010) carried out the first tests of co-integration for all stations listed on the Mexican Stock Exchange, being co-integrated variables for the period 1997-2008, with no difference between the three sectors analyzed. The relevance of the co-integration tests is attached to the "classical econometric" assumptions that observed data come from a stationary process (meaning that means and variances are constant over time), in this study the test was done under Johansen (1988) considerations, and the results showed that the Ohlson model has robust results for Mexican data.

Recently there have been similar studies in emerging markets, highlighting the work of Martinez, Prior and Rialp (2012) for Latin American equities. And in other countries, there are results of found evidence of Ohlson model in Naim and Qabajeh (2012) which are similar with respect to Mexico, for the Jordan Stock Exchange market. 


\section{Methodology}

First, we applied the methodological criteria followed, by Bukit and Iskandar (2009), about the calculation of the modified Jones model (1991), consistent with the definition criteria of Dechow (1994) for the measure the discretionary portion of the information accrued (DAI) in the financial statements in cross-sectional analysis of the years 2007, 2008 and 2009 (in order to identify any contrasting behavior before, during and after the crisis Global 2008). Besides that, we test the significance of the model, under panel data analysis.

For the second part of the study (when we add the modified Jones' model variable on the Ohlson model), we analyzed the impact of "residuals (DAI variable)" of modified Jones' model in the stock price share of selected Mexican' companies, as investor response about it. For this part we consider the dependent variable (the stock price) one period after the independent variable period, according to the methodology of Collins, Maydew and Weiss (1997) and by adding a third independent variable: the discretionary accrual information (DAl) contained in the absolute value of the residuals (of modified Jones' model estimated on the first part).

\section{Research Hypothesis}

First hypothesis: the modified Jones model is valid in all three cuts per year: 2007, 2008 and 2009, seeking to find difference in behavior for the period of crisis in the country before, during and after.

Second hypothesis: the modified Jones model is valid under panel data analysis for the 1st. study period (from the 4th quarter of 2000 to 4th quarter of 2011), based on annual closing data.

Third hypothesis: the modified Jones' model is tested as an independent variable impact on the returns of the stock price variable after one quarter, for the 1st. study period: from the 4th quarter of 2000 to 4th quarter of 2011 (based on annual closing data).

Fourth hypothesis: Discretionary Accrual variable (identified in the modified Jones' model as it residual) is added (as the third explanatory variable for the share price one quarter after) in the Ohlson model (1994), the 1st. study period: from the 4th quarter of 2000 to 4th quarter of 2011 (based on annual closing data).

\section{Studied Models}

The model used for the first and second hypotheses is the modified Jones' model (1991) which is detailed below in Equation 1. Importantly, we must emphasize that each variable is deflated by total assets before a period of time, to avoid heteroscedasticity problems, according to Chung, et al (2005):

$\mathrm{TAl}_{\mathrm{it}} / \mathrm{TA}_{\mathrm{it}-1}=\alpha_{0}\left(1 / \mathrm{TA}_{\mathrm{it}-1}\right)+\alpha_{1}\left(\left(\Delta \operatorname{Rev}_{\mathrm{it}}-\Delta \mathrm{AR}_{\mathrm{it}}\right) / \mathrm{TA}_{\mathrm{it}-1}\right)+\Delta_{2}\left(\Delta \mathrm{PPE} \mathrm{it}_{\mathrm{it}} / \mathrm{TA}_{\mathrm{it}-1}\right)+\varepsilon \mathrm{it}$ 
where:

$\mathrm{TAl}_{\mathrm{it}}$ : Total accrual information for firm $\mathrm{i}$, in the quarterly period $\mathrm{t}$ (calculated in equation 2)

$\mathrm{TA}_{\mathrm{it}-1}$ : Total assets of firm $\mathrm{i}$, in the quarterly period $\mathrm{t}-1$,

$\Delta \operatorname{Rev}_{\mathrm{it}}$ : Change in revenue (previous year) of firm $\mathrm{i}$, in the quarterly period $\mathrm{t}$,

$\Delta A R_{i t}$ : Change in accounts receivable (previous year) of firm $i$ in the period quarter $t$,

$\triangle \mathrm{PPE}_{\mathrm{it}}$ : Change in Property, Plant and Equipment Gross (previous year) of firm i in quarterly period $t$, and

$\varepsilon_{i t}$ : Other relevant information of firm $i$ in the quarterly period $t$, being orthogonal to independent variables

The Total Accrual Information variable for firm i in period t quarterly: (TAI) is calculated with the equation number 2 :

TAl $_{\text {it }}:\left(\Delta\right.$ Current Assets $_{\text {it }}-\Delta$ Cash $\left._{i t}\right)-\left(\Delta\right.$ Short-term liabilities $_{i t}-\Delta$ Short-term debt $_{i t}-\Delta$ Taxes payable $\left.{ }_{i t}\right)$ - depreciationit

where:

$\Delta$ represents the change in year $\mathrm{t}-1$ to year $\mathrm{t}$ of each concept identified in the financial statements of the company $i$, in the quarterly period $t$.

In order to identify the portion of the Discretionary Accrual Information we considered the total accrued information (TAI) as the sum of the accrued discretionary information (DAI) and accrued nondiscretionary (NDA). That is, according to the equation number 3:

$\mathrm{TAI}_{\mathrm{it}}: \mathrm{DAI}_{\mathrm{it}}+\mathrm{NDA}_{\mathrm{it}}$

DAl is defined as the residual of equation 1, while NDA is defined as the set values of equation 1. This approach is consistent with the literature, where DAI is considered as the result of the opportunities for decision makers as alternatives that the managers selected of accounting methods.

The first hypothesis was tested under cross-sectional analysis on three points: 4th annual closures of: Quarter of 2007, 2008 and 2009.

The second hypothesis was tested by panel data analysis for the 48 quarters of the study (the 1st. Quarter 2000 to 4th. Quarter of 2011).

The model used to test the third hypothesis is specified in equation 4:

$\Delta \mathrm{P}_{\mathrm{it}+1}=\alpha_{1 \mathrm{it}}\left[\left(\mathrm{TAl}_{\mathrm{it}} / \mathrm{TA}_{\mathrm{it}-1}-\left(1 / \mathrm{TA}_{\mathrm{it}-1}\right)-\left(\left(\Delta \mathrm{Rev}_{\mathrm{it}}-\Delta \mathrm{AR}_{\mathrm{it}}\right) / \mathrm{TA}_{\mathrm{it}-1}\right)-\left(\Delta \mathrm{PPEit} / \mathrm{TA} \mathrm{it}-1_{1}\right)\right]+\varepsilon_{\mathrm{it}}\right.$

where:

Equation 1 is incorporated as an independent variable to explain the change in the price a quarter later, looking for evidence of response from the stock market. The definition of the variables is the same as specified above. The only change is the 
definition of the dependent variable which is identified as: $\Delta \mathrm{P}_{\mathrm{it}+1}:$ Change in the share price of firm $\mathrm{i}$, in the quarterly period $\mathrm{t}+1$.

We performed panel data analysis for the 48 quarters of the study (the 1st. Quarter 2000 to 4th. Quarter of 2011). We used the change in financial reporting variables, as they are non-stationary series, in order to avoid spurious regressions.

The model used to test the fourth hypothesis is detailed in equation number 5 :

$\Delta \mathrm{P}_{\mathrm{it}+1} 1=\alpha_{0 i \mathrm{t}}+\alpha_{1 i \mathrm{t}} \Delta \mathrm{BV} \mathrm{it}_{\mathrm{it}}+\alpha_{2 \mathrm{it}} \Delta \mathrm{E}_{\mathrm{it}}+\alpha_{3 i \mathrm{t}} \mathrm{R}_{\mathrm{it}}+\varepsilon_{\mathrm{it}}$

where:

$\Delta \mathrm{P}_{i t+1}$ : Change in the share price of firm $\mathrm{i}$, in the quarterly period $\mathrm{t}+1$.

$\Delta \mathrm{BV}_{\mathrm{it}}$ : Change in book value of firm $\mathrm{i}$, in the quarterly period $\mathrm{t}$,

$\Delta \mathrm{E}_{\text {it }}$ : Change in the profit or loss of the company $\mathrm{i}$, in the quarterly period $\mathrm{t}$, $\mathrm{R}_{\mathrm{it}}$ : Absolute value of residuals obtained Ec.1, for firm $\mathrm{i}$, in the quarterly period $t$

$\varepsilon_{\text {it }}$ : Other relevant information of firm $\mathrm{i}$ in the quarterly period $\mathrm{t}$, being orthogonal to the independent variables

For this model we also performed panel data analysis for the 48 quarters of the study, and we used the change in the variables, as they are non-stationary series, in order to avoid spurious regressions.

\section{Characteristics of the Database}

The data analyzed was obtained from the MSM (Mexican Stock Market, in Spanish: Bolsa Mexicana de Valores: BMV). Currently (2012), it is composed by 124 active companies. The CPI (Index of Prices and Quotations, in Spanish: Índice de Precios y Cotizaciones: IPC) is the main indicator of the Mexican Stock Exchange, the performance expressed in terms of changes in the stock market price of a balanced sample, weighted and representative of all shares traded on the Stock Securities and serves as the underlying financial products.

The number of stocks companies that belong to the Price Index (IPC) is 35 series. The sample used in the calculations is made of the companies of different economic sectors. Table 1 showed the companies that belong to the IPC and that met the criteria of the models of this study, in the table we added the identification of the economic sector activity of each one. We must emphasize that we leave out the financial sector companies (because of the difference in accounting standards criteria used for financial reporting). The purchasing power of the accounting and financial information (took from the queried database of Economatica) is with the currency denomination of constant Mexican pesos as of 30 April 2012 (this is relevant because the average annual inflation in Mexico, in the study period was around $4 \%$ ).

The independent variables are financial accounting information taken from the consolidated financial statements, and they are used at the end of each quarterly period and the share price used in the next quarter of the accounting data. 


\section{Empirical Results}

Results are presented according to each hypothesis tested. We considered the "t-statistic" to verify that if a independent variable is significant or not. We are not testing how well the model is used, only if the independent variables have value relevance to the dependent variable (if they were affecting it or not).

\section{First hypothesis:}

Significance of residuals of the modified Jones' model (from equation number 1), in three annual cuts of study: 2007, 2008 and 2009.

We estimated the modified Jones' model under the specifications mentioned in the methodology and the residuals were obtained (as a measure of discretionary accrual information, DAI).

The calculation of these residuals was performed according to the methodology for calculating a prediction error similar to the standard used by Patell (1976). For each prediction error we calculated an estimated standard deviation. If the prediction errors are normally distributed, then the following relationship holds over the prediction errors of the standard deviation, with a t-distribution with $\mathrm{Ti}-3$ degrees of freedom: $\mathrm{V}_{\text {it }}=\mathrm{u}_{\text {it }} / \sigma$ (uit)

This statistic $\left(\mathrm{V}_{\mathrm{it}}\right)$ is used as a measure of "standardized prediction errors." Following the methodology of Patell, the central limit theorem is presented for the next statistical calculation in equation No. 6 :

$$
Z_{V p}=\sum_{i=1}^{N} V_{i p} /\left[\sum_{i=1}^{N}\left(T_{i}-3\right) /\left(T_{i}-5\right)\right]^{1 / 2}
$$

This measure $Z$ (calculated for the 4th quarter of the years 2007, 2008 and 2009) is asymptotically distributed as a standard deviation unit, considering that the forecast errors are independent across. In this test, the null hypothesis is that the average prediction error (i.e. discretionary accrual information) is greater than or equal to zero. The interpretation of the result can show the existence or nonexistence of Accrued Discretionary Information (DAI). In this case $\mathrm{T}$ is equal to 12 (being the total number of years of observations from 2000 to 2011). Below, in Table 1, there are the results of analyzes of these 3 years of study: 
Table 1. $Z$ statistic calculated, where the decision value is $>=$ to -1.65 (being one-tailed test), indicating that if there Accrued Discretionary Information (DAl), which makes it susceptible to the financial information to be manipulated

\begin{tabular}{|l|l|l|l|}
\hline Period & \multicolumn{2}{|l|}{ Result } & Interpretation \\
\hline 2007-4to.Quarter & $Z=$ & 0.878 & There is Discretionary Accrual information \\
\hline 2008-4to.Quarter & $Z=$ & -0.873 & There is Discretionary Accrual information \\
\hline 2009-4to.Quarter & $Z=$ & -0.144 & There is Discretionary Accrual information \\
\hline
\end{tabular}

Interpretation:

The results in Table 1 show no change in the years prior, during and after crisis. However, the presence of "Discretionary Information Accrued Information: DAl" implies that management is taking advantage of alternative decisions accounting, to present the results for the year.

\section{Second hypothesis:}

This hypothesis was focused to find significance of the variables modified Jones model in panel data analysis, for the 1st study period: from the 4th quarter of 2000 to 4th quarter of 2011 (based on annual closing data each quarter, in total there were 48 observations).

Analysis was performed by panel data, where we found autocorrelation problems (these statistics are shown in the first part of Table 2). Then the model was made incorporating a Settings Auto-Regressive of order 1 and offset independent variables in one period (the second part of Table 2). And finally fixed effects are incorporated (the third part of the Table 2). In the second and third of these adjustments, we found strength in the econometric modified Jones' model, under panel data (in terms of meeting the assumptions necessary to accept a model).

Table 2. Estimating panel data analysis of the model parameters modified Jones, according to the three stages of analyzing the second study hypothesis. It is noted with * significant at $5 \%$

\begin{tabular}{|c|c|c|c|c|c|c|c|c|}
\hline \multicolumn{3}{|c|}{$\begin{array}{l}\text { First Stage: Original Panel original, without adjustments } \\
\text { with autocorrelation }\end{array}$} & \multicolumn{3}{|c|}{$\begin{array}{l}\text { Second Stage: Panel with AR(1) and one period after of } \\
\text { the independent variables }\end{array}$} & \multicolumn{3}{|c|}{$\begin{array}{l}\text { Third Stage: Panel with AR(1), one period after of } \\
\text { the independent variables with fixed effects }\end{array}$} \\
\hline \multirow{5}{*}{$\begin{array}{l}1 / \mathrm{TA}_{i t-l} \\
\left(\Delta \operatorname{Rev}_{i t}-\Delta \mathrm{AR}_{i t}\right) / \mathrm{TA}_{i t-l} \\
\Delta \mathrm{PPE}_{i t} / \mathrm{TA}_{i t-l}\end{array}$} & \multirow{3}{*}{$\begin{array}{r}\text { Coefficient } \\
-32201.83 \\
496.44\end{array}$} & \multirow{2}{*}{$\begin{array}{r}\text { T-statistic } \\
-2.35\end{array}$} & \multicolumn{3}{|c|}{ Coefficient $\quad$ T-statistic } & \multirow{3}{*}{$\begin{array}{l}\text { Constant } \\
\left(1 / \mathrm{TA}_{\mathrm{it}-1}\right)(-1)\end{array}$} & \multicolumn{2}{|c|}{ Coefficient $\mathrm{T}$-statistic } \\
\hline & & & $\left(1 / \mathrm{TA}_{i t-1}\right)(-1)$ & -13738.57 & -0.28 & & -0.04 & $-22.90 *$ \\
\hline & & 1.97 & $\left(\left(\Delta \operatorname{Rev}_{i t}-\Delta \mathrm{AR}_{i t}\right) / \mathrm{TA}_{i t-l}\right)(-1)$ & 42.47 & 0.54 & & -44901.68 & -0.99 \\
\hline & -0.04 & $-56.52 *$ & $\left(\Delta \mathrm{PPE}_{i t} / \mathrm{TA}_{i t-1}\right)(-1)$ & 0.01 & $6.59 *$ & $\left(\left(\Delta \operatorname{Rev}_{\mathrm{it}}-\Delta \mathrm{AR}_{\mathrm{it}}\right) / \mathrm{TA}_{\mathrm{it}-1}\right)(-1)$ & 25.64 & 0.31 \\
\hline & & & $\operatorname{AR}(1)$ & 0.99 & $300.77 *$ & $\left(\Delta \mathrm{PPE}_{\mathrm{it}} / \mathrm{TA}_{\mathrm{it}-1}\right)(-1)$ & 0.01 & $6.07 *$ \\
\hline
\end{tabular}

Interpretation:

It is important to note that the third independent variable (corresponding to the change in property, plant and equipment under the deflator factor of total assets a quarter earlier) was the only one with significance for the selected Mexican companies tested (in the three stages of analysis) according with the t-statistic of the independent variables. 


\section{Third hypothesis:}

We test the significance of the modified Jones' model (as an independent variable) in the stock price after one quarter, for the 1st study period from the 4th quarter of 2000 to quarter of 2011 (based on annual closing data). It is significant, besides this result we evaluated the possibility of fixed effects existence bur it was rejected. Below in Table 3, we present the estimate:

Table 3. Estimating panel data analysis of the modified Jones model, as an independent variable that affects the stock price change is noted with * significant at $5 \%$

\begin{tabular}{|lcrl|}
\hline \multicolumn{4}{|c|}{ Original panel without adjustments } \\
\hline & Coefficient & T-statistic & \\
Jones Model & -0.057 & -6.595 & $*$ \\
& & & \\
\hline
\end{tabular}

Interpretation:

When we test the modified Jones' model (as an independent variable effect on stock price) we found that it is significant to the change in stock price. This lets us to consider the importance of financial information Total Accrued (TAI) minus adjustments nondiscretionary information (NDA), taking an approach of significance Discretionary Accrued Information (DAl). That's why we decided to test DAl as additional independent variable on the Ohlson model.

\section{Fourth hypothesis:}

We expect to find significance of Discretionary Accrual Information (DAI) variable (identified in as residual in modified Jones' model), which is added as a third explanatory variable) in the Ohlson model. For this we considered 46 quarters of study (on year-end basis for each quarter). The residuals are considered according to the literature of the "earnings quality" of financial reporting information, in absolute values.

The panel data analysis was performed in differences. Below are the results:

Table 4. Panel data of Ohlson model with the residual variable estimation. * It is significant with $5 \%$ significance

\begin{tabular}{|lrcc|}
\hline & Coefficient & T-statistic & \\
$\alpha_{0}$ & 1.717 & 1.970 & \\
$\Delta \mathrm{BV}$ & 1.407 & 8.277 & $*$ \\
$\Delta \mathrm{E}$ & 3.225 & 14.003 & $*$ \\
$\mathrm{R}$ & 11.975 & 0.065 & \\
\hline
\end{tabular}


Interpretation:

In Table 4 we find that the Ohlson model variables: Book value and Net income are significant and the variable that was added (the residuals of the modified Jones' model) is not significant. This means that the Discretionary Accrual Information (DAI) does not provide additional relevant information to the Ohlson model, one explanation of this evidence is that the accrual information is implied in the two original variables of the Ohlson model.

\section{Conclusions}

In this paper we analyzed the significance of the modified Jones' model (1991) from several perspectives. The importance of this model emphasize on the presence of Accrued Discretionary Information, which becomes important in the light of the quality of earnings presented in financial reports, both for managerial decision making (internal management), and for potential investment of shareholders. We assessed the significance of this variable in terms of the relevance value that means for the stock price.

We found evidence for the existence of this information Discretionary Accrued Information (DAI) on analysis specified years (2007, 2008 and 2009) without contrast behavior in the studied periods of before, during and after the international crisis of 2008.

The modified Jones' model (1991) was tested to selected Mexican' companies (the ones that belong to the IPC and met the models' characteristics of the study period of 2000-2011). We identified that the following variable was the only one with value relevance for Mexican behavior (in terms of DAI): change in Property, Plant and Equipment. This variable represents the decision making of long-term investment, and it seems that it has the reflection of total information accrual significance, according to the tests (even under the analysis of panel data, fixed effects or as well without them).

Finally, we incorporated the residuals of the modified Jones' model (DAI) in the Ohlson model (which is significant for Mexican data, as was it shown in Duran and Lorenzo (2010)). This paper adds Discretionary Accrual Information (DAI variable), and it was found that is not statistically significant (under t-statistic criteria) and we conclude that it does not affect prices or it could be a highly correlated relation between variables, indicating that DAl characteristics could be incorporated into Book Value or Earnings. We will continue researching about this implication, in terms of the relevance of the financial information on fundamental analysis of corporate finance.

\section{References}

Aminul Md., Ali R., and Ahmad Z. (2011). Is Modified Jones Model Effective in Detecting Earnings Management? Evidence from a Developing Economy. International Journal of Economics and Finance, 3, 2, May 2011, 116-125.

Azofra V., Castrillo L. and Delgado M. (2006). Evaluación de los modelos de ajustes por devengo: ajustes discrecionales a informes de auditoria con salvedades. Revisa Partida doble, 181, 88-104. 
Ball R. and Brown P. (1968). An Empirical Evaluation of Accounting Income Numbers. Journal of Accounting Research, 6, 2, 159-178.

Barth, M.E., Cram D.P. and Nelson K.K. (2001). Accruals and the prediction of future Cash Flows. The Accounting Review, 76, 1, $27-58$.

Bukit B.R. and Iskandar M. (2009). Surplus Free Cash Flow, Earnings Management and Audit Committee. Journal of Economics and Management, 3 (1), 204-223.

Castrillo, L.A. and San Martín, J.M. (2008). Los ajustes por devengo como medida de discrecionalidad directiva. Revista de Contaduría y Administración, 226, sept-dic, 9-37.

Collins, D.W., E.L. Maydew, e I.S. Weiss, (1997). Changes in the value-relevance of earnings and book values over the past forty years. Journal of Accounting and Economics, 24(1), 39-67.

Chung, R., Firth, M. and Kim J.B. (2005). Earnings management, Surplus Free Cash Flow and External Monitoring. Journal of Business Research, 58, 766-776.

Davis-Friday, P., Rivera, J. (2000). Inflation accounting and 20-F disclosures: Evidence from Mexico. Accounting Horizons Journal, 14, 113-135.

DeAngelo, L.E. (1986). Accounting numbers as Market Valuation Valuation Substitutes: A Study of Management Buyouts of Public Stockholders. The Accounting Review, 61, 400-420.

Dechow, P.M., (1994), Accounting earnings and cash flows as measures of firm performance: The role of accounting accruals. Journal of Accounting and Economics, 18(1), 3-42.

DeFond, M.L., and Subramanyam, K.R. (1998). Auditor Changes and Discretionary Accruals, Journal of Accounting and Economics, 25, 2, 35-67.

Durán, R., Lorenzo A. and Valencia H. (2007). Value relevance of the Ohlson model with Mexican data. Revista de Contaduría y Administración, 1, 223, UNAM, SeptiembreDiciembre, 33-52.

García B. and Gill-deAlbornoz, B. (2005). Gobierno corporativo y las prácticas de earnings management: evidencia empírica en España. Instituto Valenciano de Investigaciones Económicas S.A., Abril 2005, 1-46.

Hansen, G.A. and Noe C.F. (1998). Do Managers' Accrual Decisions Speak Louder than Words?, Journal of Accounting and Economics, 7, April, 85-107.

Healy, P.(1985). The impact of Bonus schemes on the selection of Accounting Principles. Journal of Accounting and Economics, 7, 85-107.

Johansen (1988). Statistical analysis of cointegration vectors. Journal of Economic Dynamics and Control, 12, 231-254.

Jones, J. (1991). Earnings Management during Import Relief Investigations. Journal Accounting Research, 1995, 213-228.

Lomelí Venegas L. and Muruyama C. (2009) .México frente a la crisis: hacia un nuevo curso de desarrollo. Revista de Economía UNAM, 6, 18, 7-60. 
Lorenzo A. and Durán R. (2010). Ohlson model by panel cointegration with Mexican data. Revista de Contaduría y Administración 1, 232, UNAM, Septiembre-Diciembre, 131-142.

Martínez P., Prior D. and Rialp J. (2012). The Price of stocks in Latin American financial markets: an empirical application of the Ohlson model. Global conference on business and finance proceedings, 7, 96-100.

McNichols, M. and Wilson, G.P. (1988). Evidence of Earnings Management from the Provision for Bad Debts. Journal of Accounting Research, 26, 1-31.

Naim F. and Qabajeh. Value relevance of Ohlson model with Jordanian data. Interdisciplinary Journal of contemporary research in business. 3, 11, 551-560.

Ohlson, J. A. (1995). Earnings, books values and dividends in equity valuation. Contemporary Accounting Research, 11(2), 661-687.

Patell J.M. (1976). Corporate forecast of Earnings per share and Stock Price Behavior: Empírical Tests. Journal of Accounting Research, 14 (Autumn 1976), 246-276.

Poveda F. (2001). Cuestiones estadísticas sobre modelos y constrates de ajustes por devengo anormales. Working paper, Instituto Valenciano de Investigaciones Económicas, julio, 1-52.

Shvakumar L. (1996). Essay Related to Equity Offerings and Earnings Management. Dissertation, Vanderbilt University.

Subramanyam K.R. (1996). The Pricing of Discretionary Accruals. Journal of Accounting and Economics, 22, 1, 3-27

Xie B., Davison, W.N and DaDalt, PK. (2003). Earnings Management and Corporate Governance: The Role of the Board and the Audit Committee. Journal of Corporate Finance, 9, 295-316.

\section{Abstract (in Polish)}

Niniejsza praca stosuje zmodyfikowany model Jones'a (1991) wykorzystujqc dane finansowe wybranych firm meksykańskich. Celem modelujestocena wpływu Discretionary Accrual Information (DAl) na zawartość sprawozdań finansowych w celu identyfikacji wartości "jakości zysku”. Praca stosuje kryteria metodologiczne zaproponowane w Chung et al (2005) i Mukit \& Iskandar (2009). Autorzy poddali analizie finansowe dane 35 firm, których akcje występowały w indeksie cen i cytowań (IPC) na Mexican Stock Exchange (BMV) w okresie 2000 do 2011. 19 firm spełniło specyfikacje modelu biorqc pod uwagę dane kwartalne w okesie 12 lat będqcych przedmiotem rozważań. Analiza została przeprowadzona w trzech etapach: najpierw, analiza zmodyfikowanego modelu Jones'a na danych panelowych przy użyciu efektów stałych i modyfikacji wynikajq̨cych $z$ autokorelacji rzędu pierwszego; analiza korelacji pomiędzy wartościami rezydualnymi zmodyfikowanego modelu Jones'a i stopq zwrotu z akcji w trzech kolejnych latach analizy: 2007, 2008 i 2009; test modelu Ohlsona z użyciem zmiennej DAl, danych panelowych i efektów stałych w rozważanym horyzoncie czasowym.

Słowa kluczowe: rynki finansowe, modele Jones'a i Ohlson'a, ekonometryczne oszacowania. 